\title{
Morphometric Relationships Between the Hermit Crab Isocheles sawayai (Forest \& Saint Laurent) (Crustacea Anomura Diogenidae) and its Shell from Southern Brazil
}

\author{
S. Masunari ${ }^{*}$, A.M. Fontanelli and S.R. Sampaio \\ Department of Zoology, Federal University of Paraná, Brazil
}

\begin{abstract}
A study on morphometric relationships between the hermit crab Isocheles sawayai and its shell in a population from Paraná-Santa Catarina States coast was carried out. Hermit crabs from the by-catch of shrimp fishing (4-15m depth) were collected. Cephalothoracic shield length (CL) and width (CW) from hermit crabs and total length (SL), aperture length (AL) and weight (SW) from shells were taken. A total of 266 hermit crabs occupying eight species of shell - Buccinanops lamarckii, Dorsanum moniliferum, Oliva reticularis, Olivancillaria steeriae, O. urceus, Polinices hepaticus, Semicassis granulatum and Stramonita haemastoma - were obtained. Males $(\mathrm{N}=189)$ that dominated strongly $(1 \mathrm{M}: 0.4$ F) occupied eight shell species, while females $(\mathrm{N}=76)$ occupied only six. There was only one intersex individual that occupied a Stramonita shell. Contrarily to intertidal populations, O. urceus was the most frequently occupied shell by males $(57.14 \%)$ and females $(62.33 \%)$ in this studied area. Due to the smaller size of females (mean CL $5.19 \pm 0.84 \mathrm{~mm}$ ), these ones occupied shells of a smaller size than males (mean CL $6.49 \pm 1.14 \mathrm{~mm}$ ). The highest $O$. urceus shell frequency of occupation is connected to the hermit crab's life style: it is a filter feeding species and its shell remains totally buried in the sandy substratum having only its cephalothoracic appendages free. The heavy shell of this gastropod (highest SW/SL) favors the stability in strong current water conditions, as it functions as an anchorage for this semi-buried hermit crab.
\end{abstract}

\section{INTRODUCTION}

Hermit crabs are extremely dependent on empty gastropod shells, as they need to protect their delicate abdomen inside them. The capital importance of this need can be observed in times of unavailability of this resource, when the hermits are able to occupy a variety of alternative protectors such as conical shells of scaphopods, serpulid tubes, cavities of pebbles, sponges, dead corals, bamboo pieces and shells of bivalve [1]. On the other hand, there were hermit crabs occupying gastropod shells covered by alive corals, bryozoans and barnacles reported from southern Brazil [2]. The selection of the gastropod shell to be occupied by a hermit crab is related to several factors, among which the shell availability in the habitat has been considered the most important one [3] and confirmed by several authors of different countries [4]. The shell's weight and its internal volume [5$11]$ and physical factors $[12,13]$ have been reported as a secondary factor. On the other hand, males and females can occupy different species of empty shells as reported in Brazilian hermit crab populations $[7,8,10,11]$. In case of low availability of gastropod shells and hermit crabs were forced to occupy tight shells, negative effects such as lowered growth rates and increased susceptibility to predation by some crab species were observed [14-16]. The hermit crab Isocheles sawayai (Forest \& Saint Laurent, 1967) has a geographic distribution restricted to the Brazilian coast, from the Ceará State to the Santa Catarina State, from shallow waters to infralittoral zones of sandy beaches [17], in abundant or

*Address correspondence to this author at the Departamento de Zoologia, Setor de Ciências Biológicas, Universidade Federal do Paraná; Caixa Postal 19020, CEP 81531-990, Curitiba, PR, Brasil; E-mail: setmas@ufpr.br small populations [18-23]. Most of this hermit crab population occupy empty shells of the gastropod Stramonita haemastoma (Conrad, 1837), followed by Buccinanops sp. and Olivancillaria sp. [18, 22, 24]. Morphometric relationships between the hermit crab I. sawayai and its shell coming from shallow waters of the southeastern Brazilian coast [24] showed that most of these hermit crabs have well fitted shells. Among several pairs of dimensions, the thickness of the hermit cephalothorax and the width of the shell aperture had the closest relationship.

Another morphometric relationship study carried out with three species of intertidal hermit crab Clibanarius Dana 1852 from the São Paulo State beaches [4] clearly shows that these crabs tend to take smaller and lighter shells as they increase in size. The present study aims to describe the morphometric relationships between the hermit crab I. sawayai and its shells, in a population living in the coast of Paraná and Santa Catarina (southern Brazil). In spite of its wide distribution along the Brazilian coast, the populations of these States were not treated in this aspect.

\section{MATERIAL AND METHODS}

Hermit crabs were obtained from by-catch of shrimp fishing that was carried out with gill nets of 2.0 to $3.0 \mathrm{~cm}$ mesh, in depths from 4 to $15 \mathrm{~m}$ along Paraná and Santa Catarina States coast, southern Brazil, on October, $6^{\text {th }}, 2001$, January, $20^{\text {th }}, 2002$ and October, $7^{\text {th }}, 2002$. In the laboratory, the hermit crabs were extracted from the shells, labeled, and preserved in alcohol $70 \%$, while the properly labeled shells were dried in room temperature till their weight became constant. Crabs were identified, sexed and, ovigerous females were recorded. In the graphs of Figs. (1) and (4), the intersex crab was included to the male group, as it is a functional 
male without any indications to be hermaphroditic [25]. The length (CL-between anterior and posterior margins) and the maximum width $(\mathrm{CW})$ of cephalothoracic shield were measured with a digital caliper of $0.01 \mathrm{~mm}$ error. CL was used as a reference measurement in correlation analysis in order to do compare with results reported by previous authors [24]. In the study of the population structure, males ( + intersex) and females were distributed separately in CL classes with $0.30 \mathrm{~mm}$ range, that were identified by respective middle values.

The shells occupied by hermits were identified and weighted (SW) with an electronic scale of $0.01 \mathrm{~g}$ error, and their total length (SL-between both extremities), and the length (AL) and the width (AW) of the shell aperture were measured with a manual caliper of $0.05 \mathrm{~mm}$ error. The relative length of the shell aperture was estimated as the ratio between AL and SL. Similarly, the relative weight of the shell was calculated as the ratio between SW and SL.

Average values and standard deviation were calculated and histogram construction were done with the aid of STATISTICS software for microcomputers. The frequencies of each shell occupation were compared through $\mathrm{X}^{2}$ test. The relationships between $\mathrm{CL}$ and various shell parameters were calculated through linear function $(y=a x+b)$ or power function $\left(y=a x^{b}\right)$ [26].

\section{RESULTS}

A total of 266 hermit crabs of Isocheles sawayai were obtained, among these 189 were males, 76 females and one intersex. Six ovigerous females (three from the in October month sample and three from the January month sample) were recorded; however, due to the low frequency, they were treated without discrimination with other females. The hermit crabs occupied empty gastropod shells of eight species: Buccinanops lamarckii (Kinner, 1834), Dorsanum moniliferum (Valenciennes, 1834), Oliva reticularis Lamarck, 1811, Olivancillaria steeriae (Reeve, 1850), Olivancillaria urceus (Röding, 1798), Polinices hepaticus (Röding, 1798), Semicassis granulatum (Born, 1778) and Stramonita haemastoma.

$\mathrm{CL}$ and $\mathrm{CW}$ of the hermit crabs varied from 2.97 to $8.80 \mathrm{~mm}$ and 2.84 to $8.86 \mathrm{~mm}$, respectively, in a linear relationship in the dispersion graph. The equation of this relationship is $\mathrm{Y}=0.9901 \mathrm{X}+0.0082, \mathrm{R}^{2}=0.98$. The average CL of males was $6.49 \pm 1.14 \mathrm{~mm}$ while the females average was $5.19 \pm 0.84 \mathrm{~mm}$ (Table 1).

Males (+ intersex) were distributed into $20 \mathrm{CL}$ classes, predominant in bigger CL values, while females into $14 \mathrm{CL}$ classes, predominant in smaller ones (Fig. 1). Males occupied all recorded shell species, while females, only in six of them. These shells measured from 19.85 to $60.55 \mathrm{~mm}$ SL, among them the Buccinanops which was the largest one with $50.66 \mathrm{~mm}$ mean SL, followed by Semicassis and O. urceus.

Shells occupied by male crabs had an average of $44.29 \pm 7.34 \mathrm{~mm}$ SL (range of 19.85-60.55mm SL), while female ones had an average of $37.27 \pm 6.25 \mathrm{~mm}$ SL (range of 23.40-53.15mm SL). Similarly, as females had a smaller size, they occupied shells with smaller mean weight $(7.68 \pm 4.45 \mathrm{~g} \mathrm{SW})$ than males $(11.74 \pm 6.08 \mathrm{~g} \mathrm{SW})$. The intersex occupied a shell of Stramonita with $40.30 \mathrm{~mm}$ SL and
$12.96 \mathrm{~g}$ SW (Table 1). The shell O. urceus had the highest frequency of occupation by I. sawayai summing up $57.14 \%$ among males and of $62.33 \%$ among females. Semicassis was the second more frequently occupied by males $(17.98 \%)$ and Stramonita by females $(22.07 \%)$.

Big sized shells such as Buccinanops and Semicassis were occupied exclusively by males or these ones dominated in this occupation (Fig. 1). However, there was not any tendency of differentiated shell occupation, in function of the hermit crab sex. Males and females occupied shells in an equivalent way, proportionally to the abundance of each sex (Table 1).

For this reason, in the shell occupation analysis both sexes were considered together.

A significant relationship (95\%) was found only between the shell species $O$. urceus because it was most frequently occupied by I. sawayai: between SL x CL (linear function Y $\left.=5.4907 \mathrm{X}+9.7051, \mathrm{r}^{2}=0.71\right)($ Fig. 2), and between SW $\mathrm{x}$ $\mathrm{CL}$ (power function $\mathrm{Y}=0.128 \mathrm{X}^{2.48}, \mathrm{r}^{2}=0.75$ ) (Fig. 3). The remainder relationships (AL x CL, AW x CL) were also significant $(\mathrm{P}<0.05)$ only in the case of shell species more frequently occupied. Furthermore, all these correlations showed a tendency to negative allometry, except for AL x CL of Stramonita and CL x AW of Buccinanops (Table 2).

There was a direct relationship between the occupation frequency of the male hermit crabs and the relative length of AL (ratio between AL and SL) of the shell species more frequently occupied: the higher the relative length of $\mathrm{AL}$, the higher the occupation frequency (Fig. 4). The relative weight (ratio between SW and SL) of most shells also showed the same tendency (Fig. 5).

\section{DISCUSSION}

The population of I. sawayai recorded in Ubatuba beach [24] was composed of 288 individuals, a very close number of the present study $(\mathrm{N}=266)$. The hermit crab CL ranges were also similar in these two populations: from 3.40 to $8.30 \mathrm{~mm}$ for males and from 3.50 to $7.20 \mathrm{~mm}$ for females in Ubatuba, and $2.97-8.80 \mathrm{~mm}$ and $3.21-7.27 \mathrm{~mm}$, respectively in the Paraná-Santa Catarina States coast (see Table 1).

The linear and power relationships between several measures of the hermit crabs and the shells are in accordance with previous works [4, 27]. Additionally, the tendency for a negative allometry in the relationship between these measures (see Table 2) is in accordance to the results obtained by former authors [4] for three species of Clibanarius. Therefore, the linear correlation between the shell parameters (SL, $\mathrm{AL}$ and $\mathrm{AW}$ ) and the hermit crab CL, and the power correlation between $\mathrm{CL}$ and $\mathrm{SW}$ recorded for $I$. sawayai seem to constitute a general rule for the hermit crabs whose morphometric relationships are known.

The occurrence of only one intersex hermit crab confirms the rarity of this sex in the populations of $I$. sawayai observed in previous paper [25] in the São Paulo State. However, the interpretation of its role is difficult, since this intersex is a functional male, according to these authors.

In the present study, the population of I. sawayai occupied almost the same spectrum of the shell species compared 
Table 1. Isocheles sawayai. Statistics for Morphometric Relationships Between the Hermit Crab and Respective Occupied Shells

\begin{tabular}{|c|c|c|c|c|c|}
\hline Hermit Crab & $\mathbf{N}$ & CL Mean & CL Min & CL Max & S.D. \\
\hline Males & 189 & 6.49 & 2.97 & 8.8 & 1.13 \\
\hline Females & 76 & 5.19 & 3.21 & 7.27 & 0.84 \\
\hline Intersex & 1 & 5.70 & 5.70 & 5.70 & 0 \\
\hline Hermit Crab & $\mathbf{N}$ & CW Mean & CW Min & CW Max & S.D. \\
\hline Males & 189 & 6.44 & 2.84 & 8.86 & 1.12 \\
\hline Females & 76 & 5.13 & 3.06 & 7.48 & 0.88 \\
\hline Intersex & 1 & 5.49 & 5.49 & 5.49 & 0 \\
\hline Shells with Males (mm) & $\mathbf{N}$ & SL Mean & SL Min & SL Max & S.D. \\
\hline Buccinanops lamarckii (Kinner, 1834) & 15 & 50.66 & 40 & 58.8 & 5.15 \\
\hline Semicassis granulatum (Born, 1778) & 34 & 45.4 & 31.65 & 56.75 & 5.07 \\
\hline Olivancillaria urceus (Röding, 1798) & 108 & 44.06 & 21.65 & 60.55 & 7.3 \\
\hline Stramonita haemastoma (Conrad, 1837) & 24 & 42.88 & 22.1 & 56.4 & 7.65 \\
\hline Dorsanum moniliferum (Valenciennes, 1834) & 2 & 40.67 & 38.55 & 42.8 & 3 \\
\hline Oliva reticularis Lamarck, 1811 & 1 & 36 & 36 & 36 & 0 \\
\hline Olivancillaria steeriae (Reeve, 1850) & 2 & 33.85 & 29.45 & 38.25 & 6.22 \\
\hline Polinices hepaticus Röding, 1798) & 3 & 29.95 & 19.85 & 36.95 & 8.96 \\
\hline Shells with Females (mm) & $\mathbf{N}$ & SL Mean & SL Min & SL Max & S.D. \\
\hline Olivancillaria urceus & 48 & 38.43 & 25.25 & 53.15 & 5.51 \\
\hline Semicassis granulatum & 7 & 36.9 & 28.9 & 45.75 & 5.34 \\
\hline Stramonita haemastoma & 15 & 35.47 & 23.4 & 50.75 & 7.76 \\
\hline Dorsanum moniliferum & 3 & 35.26 & 32.75 & 38.65 & 3.04 \\
\hline Olivancillaria steeriae & 2 & 34.17 & 25.85 & 42.5 & 11.77 \\
\hline Polinices hepaticus & 1 & 24.45 & 24.45 & 24.45 & 0 \\
\hline Shell with Intersex (mm) & $\mathbf{N}$ & SL & SL min & SL max & S.D. \\
\hline Stramonita haemastoma & 1 & 40.3 & 40.3 & 40.3 & 0 \\
\hline Shell Weight (g) & $\mathbf{N}$ & SW Mean & SW Min & SW Max & S.D. \\
\hline With males & 189 & 11.74 & 1.53 & 33.33 & 6.08 \\
\hline With females & 76 & 7.54 & 1.33 & 22.19 & 4.3 \\
\hline With intersex & 1 & 12.96 & 12.96 & 12.96 & 0 \\
\hline Shells Occupied by & $\mathbf{E F}$ ㅇ & EF ${ }^{\lambda *}$ & $\mathbf{O F} q$ & OF $\delta^{\lambda *}$ & $\mathrm{X}^{2}$ Test \\
\hline Olivancillaria urceus & 47.70 & 108.29 & 48 & 108 & $0.0018 \mathrm{NS}$ \\
\hline Semicassis granulatum & 12.54 & 28.46 & 7 & 34 & $2.4463 \mathrm{NS}$ \\
\hline Stramonita haemastoma & 11.93 & 27.07 & 15 & 25 & $0.7920 \mathrm{NS}$ \\
\hline Dorsanum moniliferum & 1.53 & 3.47 & 3 & 2 & $1.4151 \mathrm{NS}$ \\
\hline Olivancillaria steeriae & 1.22 & 2.78 & 2 & 2 & $0.4932 \mathrm{NS}$ \\
\hline Polinices hepaticus & 1.22 & 2.78 & 1 & 3 & $0.0407 \mathrm{NS}$ \\
\hline
\end{tabular}

$\mathrm{CL}$ and $\mathrm{CW}=$ cephalothoracic shield length and width; $\mathrm{SL}$ and $\mathrm{SW}$ shell length and weight; $\mathrm{N}=$ absolute number; $\mathrm{SD}=\mathrm{Standard}$ deviation; $\mathrm{R}=$ range; $\mathrm{EF}=$ expected frequency; $\mathrm{OF}$ $=$ observed frequency; $\mathrm{NS}=$ not significant. $*=$ included the only intersex. 


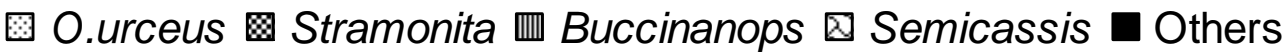
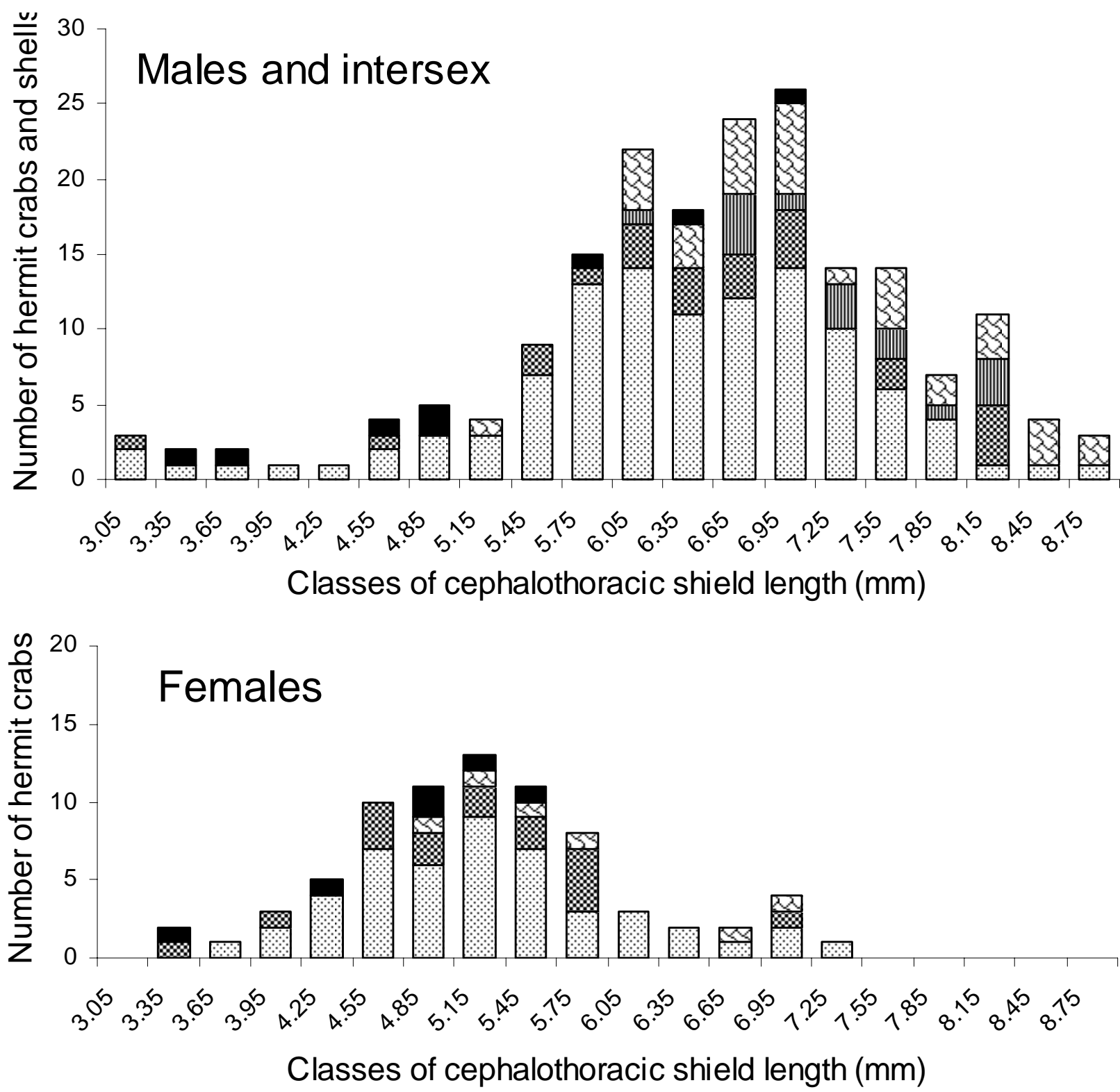

Fig. (1). Distribution of males (+intersex) and females of the hermit crab Isocheles sawayai absolute frequency into classes of cephalothorax shield length and their occupied shells.

to those from the São Paulo State. However, the dominance of $O$. urceus recorded in Paraná-Santa Catarina coast is unique. In that state, about $68 \%$ in Peruíbe beach [18] and about $80 \%$ in Ubatuba beach [24] of the hermit crabs occupied shells of Stramonita. This difference can be related with different shell availability in the intertidal areas and in deeper waters (at least $4 \mathrm{~m}$ depth in the present study). Therefore, in higher depths, shells of $O$. urceus seem to be more numerous and consequently in higher availability than in intertidal areas.

The strong dominance in the occupation of $O$. urceus shells by $I$. sawayai in deeper waters is certainly related to the possibility of its ready occupancy. This hypothesis is based on the wide size range of these shells (see Table 1).
However, this dominance can also to be connected to the hermit life style: it is a filter feeding species and its shell remains totally buried in the sandy substratum, having only its cephalothorax appendages free [28, 29]. The relatively heavy shell of $O$. urceus can contribute favorably for the anchorage of the hermit-shell set inside the sandy substratum; this stability avoids this semi-sedentary hermit crab to be dragged by the water movement. On the other hand, shells relatively light as Buccinanops were chosen by big hermit crabs, probably, due to the natural shortage of larger shells than $O$. urceus. The maximum SL recorded for $O$. urceus of $60.55 \mathrm{~mm}$ (see Table 1) sustains this assumption. This shell occupancy contrasts with that of Clibanarius erythropus (Latreille 1818) from East Atlantic shores: this hermit crab 


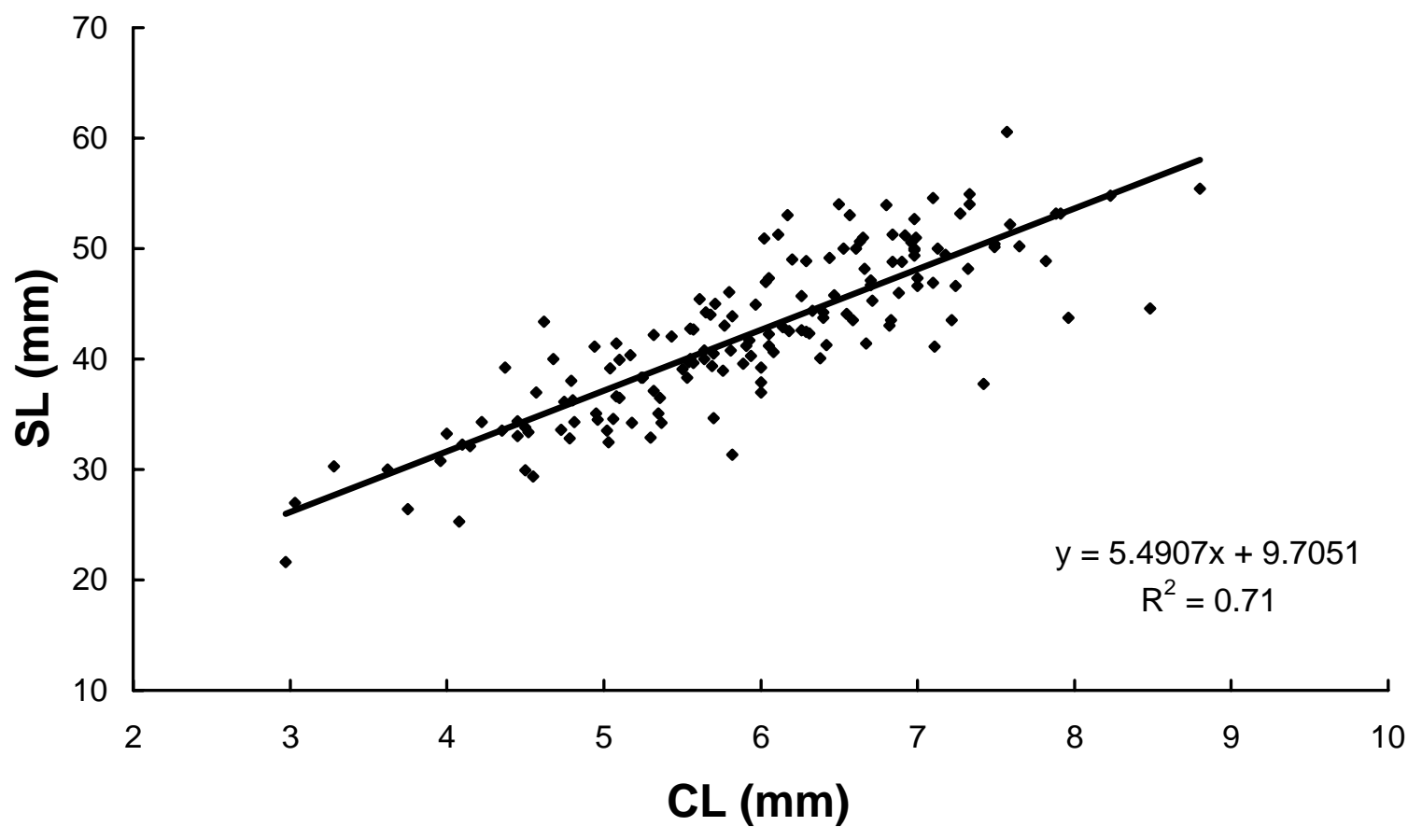

Fig. (2). Relationship between the shell length (SL) of Olivancillaria urceus and the hermit crab Isocheles sawayai cephalothorax shield length (CL).

chose elongated and lighter shells that are less energetically expensive [30].

With the exception of Stramonita, all gastropod shells occupied by I. sawayai live in sandy substratum [31]. Therefore, as soon as the shell becomes available, mainly $O$. ur- ceus, it is immediately occupied by the sympatric I. sawayai. This immediate occupation can be deduced from the integrity (shell aperture without imperfections and smooth shell surface) of almost all occupied O. urceus shells.

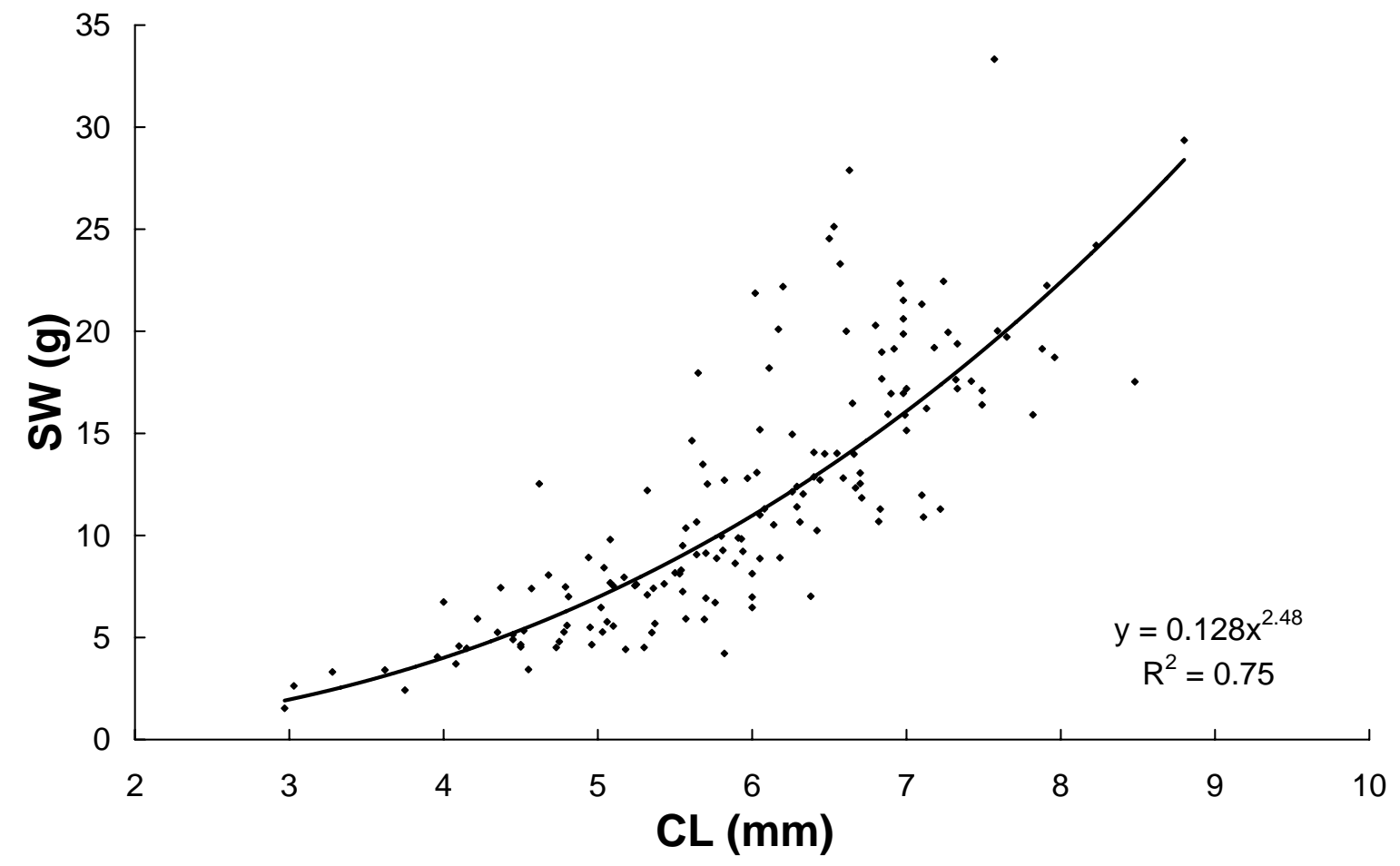

Fig. (3). Relationship between the shell weigth (SW) of Olivancillaria urceus and the hermit crab Isocheles sawayai cephalothorax shield length (CL). 


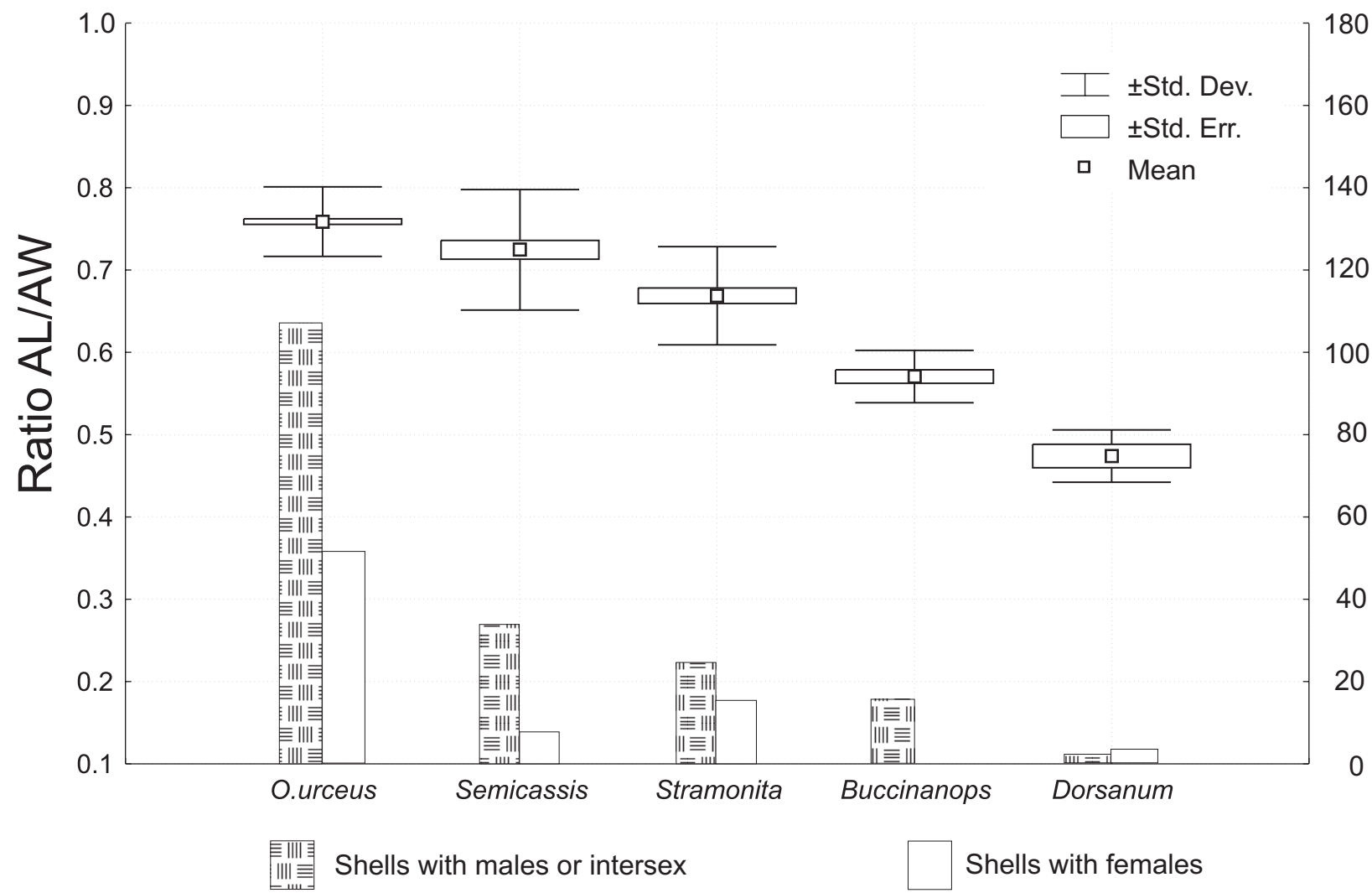

Fig. (4). Mean, standard deviation, standard error of the ratio AL/SL of the shell species more frequently occupied by the hermit crab Isocheles sawayai and absolute frequency of males (+ intersex) and females that was occupying these shells.

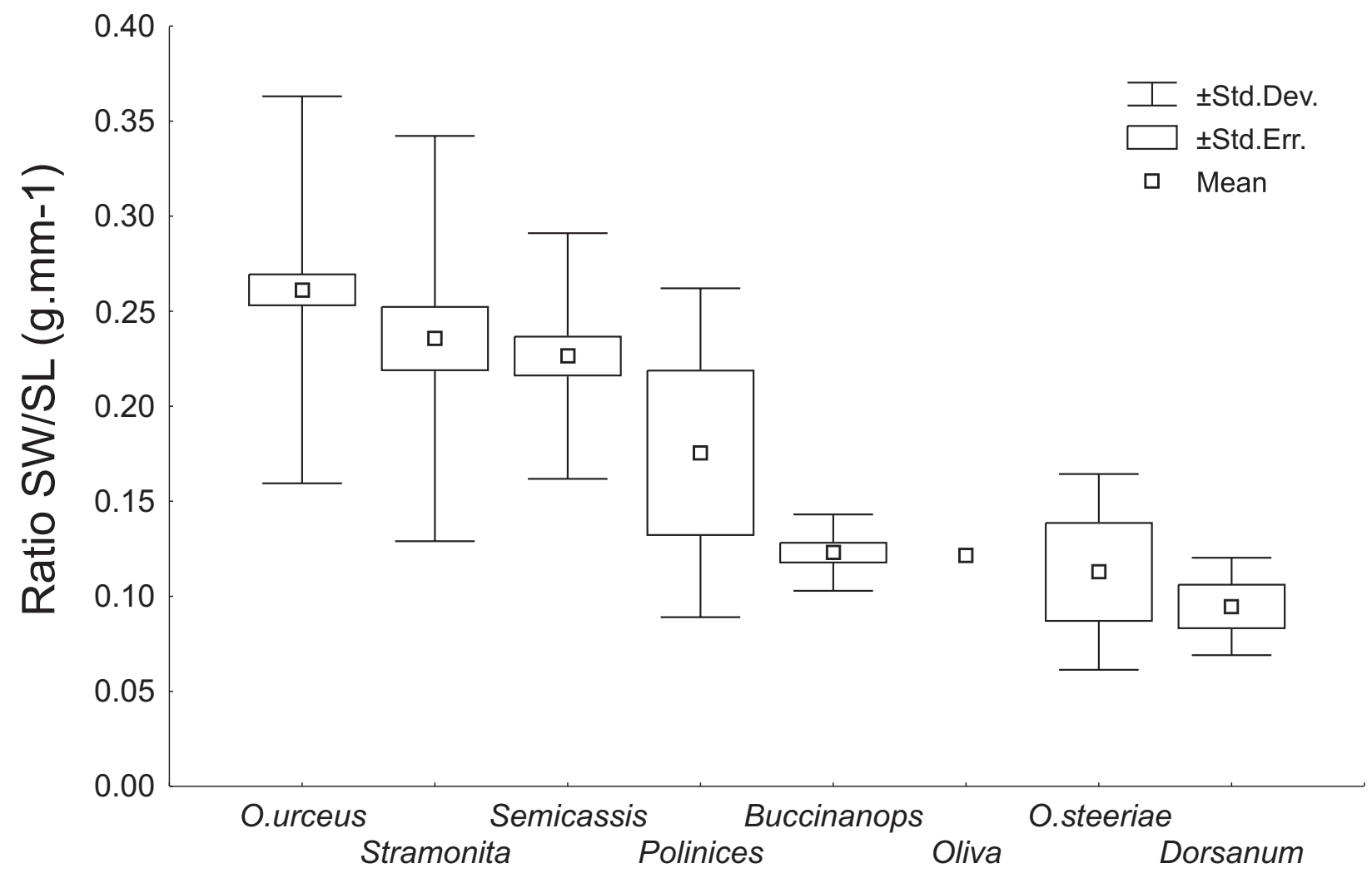

Fig. (5). Mean, standard deviation, standard error of the ratio SW/SL of the shell species occupied by the hermit crab Isocheles sawayai. 
Table 2. Isocheles sawayai. Regression Analysis $\left(y=a x^{b}\right.$ Neperian Logarithm Values) Between the Cephalothoracic Shield Length (CL) (Independent Variable) of the Hermit Crab - and Shell Length (SL) and Weight (SW) and Shell Aperture Length (AL) and Width (AW) More Frequently Occupied by Hermit Crabs

\begin{tabular}{|c|c|c|c|}
\hline Gastropod Shell Species & Relation & Equation & $\mathbf{r}^{2}$ \\
\hline \multirow{4}{*}{$\begin{array}{l}\text { Olivancillaria } \\
\text { urceus } \\
\qquad \mathrm{N}=156\end{array}$} & SL $x$ CL & $\operatorname{lnSL}=1.027+0.775 \ln C L$ & $0.7137 *$ \\
\hline & $\mathrm{SW} \times \mathrm{CL}$ & $\operatorname{lnSW}=-0.983+2.484 \ln C L$ & $0.7482 *$ \\
\hline & $\mathrm{AL} \times \mathrm{CL}$ & $\ln A L=0.858+0.838 \ln C L$ & $0.7164 *$ \\
\hline & $\mathrm{AW} \times \mathrm{CL}$ & $\ln \mathrm{AW}=0.320+0.879 \operatorname{lnCL}$ & $0.6217^{*}$ \\
\hline \multirow{4}{*}{$\begin{array}{c}\text { Stramonita } \\
\text { haemastoma } \\
\quad \mathrm{N}=41\end{array}$} & SL $x$ CL & $\operatorname{lnSL}=0.908+0.889 \operatorname{lnCL}$ & $0.7378^{*}$ \\
\hline & $\mathrm{SW} \times \mathrm{CL}$ & $\operatorname{lnSW}=-1.049+2.563 \ln C L$ & $0.6902 *$ \\
\hline & $\mathrm{AL} \times \mathrm{CL}$ & $\ln \mathrm{AL}=0.596+1.066 \operatorname{lnCL}$ & $0.7848^{*}$ \\
\hline & $\mathrm{AW} \times \mathrm{CL}$ & $\ln \mathrm{AW}=0.417+0.867 \ln \mathrm{CL}$ & $0.5600^{*}$ \\
\hline \multirow{4}{*}{$\begin{array}{c}\text { Semicassis } \\
\text { granulatum } \\
\mathrm{N}=40\end{array}$} & SL $x$ CL & $\operatorname{lnSL}=0.979+0.791 \operatorname{lnCL}$ & $0.7293 *$ \\
\hline & $\mathrm{SW} \times \mathrm{CL}$ & $\operatorname{lnSW}=-0.874+2.211 \ln C L$ & $0.6112 *$ \\
\hline & $\mathrm{AL} \times \mathrm{CL}$ & $\ln A L=0.868+0.753 \ln C L$ & $0.4554 *$ \\
\hline & $\mathrm{AW} \times \mathrm{CL}$ & $\ln \mathrm{AW}=0.495+0.651 \ln \mathrm{CL}$ & $0.4978^{*}$ \\
\hline \multirow{4}{*}{$\begin{array}{l}\text { Buccinanops } \\
\text { lamarckii } \\
\mathrm{N}=15\end{array}$} & SL $x$ CL & $\operatorname{lnSL}=0.980+0.843 \operatorname{lnCL}$ & $0.5353^{*}$ \\
\hline & $\mathrm{SW} \times \mathrm{CL}$ & $\operatorname{lnSW}=-0.737+1.777 \ln C L$ & $0.4031 *$ \\
\hline & $\mathrm{AL} \times \mathrm{CL}$ & $\ln \mathrm{AL}=0.785+0.786 \ln C \mathrm{~L}$ & $0.4895^{*}$ \\
\hline & $\mathrm{AW} \times \mathrm{CL}$ & $\ln \mathrm{AW}=0.198+1.092 \operatorname{lnCL}$ & $0.6037^{*}$ \\
\hline
\end{tabular}

\section{ACKNOWLEDGEMENTS}

To Prof. Dr. Osmar Domaneschi and Dr. Adolpho Birman from Department of Zoology, São Paulo University for the confirmations of the gastropod shell identification. To Prof. Dr. Luis Amilton Foerster from Department of Zoology, Federal University of Paraná, for the English revision. This is Contribution No. 1705 of Department of Zoology, Federal University of Paraná.

\section{REFERENCES}

[1] Imafuku M, Ando T. Behaviour and morphology of pagurid hermit crabs (Decapoda, Anomura) that live in tusk shells (Mollusca, Scaphopoda). Crustaceana 1999; 72: 129-144.

[2] Garcia RB, Meireles AL, Mantelatto FL. Unusual shelters occupied by Brazilian hermit crabs (Crustacea: Decapoda: Diogenidae). Braz J Biol 2003; 63(4): 721-722.

[3] Bertness MD. Shell preference and utilization patterns in littoral hermit crabs of the Bay of Panama. J Exp Mar Biol Ecol 1980; 48: $1-16$.

[4] Turra A, Leite FPP. Shell-size selection by intertidal sympatric hermit crabs. Mar Biol 2004; 145: 251-257.

[5] Conover MR. The importance of various shell characteristics to the shell-selection behavior of hermit crabs. J Exp Mar Biol Ecol 1978; 32(2): 131-142.
[6] Garcia RB, Mantelatto FL. Shell selection by the tropical hermit crab Calcinus tibicen (Herbst, 1791) (Anomura, Diogenidae) from southern Brazil. J Exp Mar Biol Ecol 2001; 265: 1-14.

[7] Mantelatto FL, Garcia RB. Shell utilization pattern of the hermit crab Calcinus tibicen (Diogenidae) from southern Brazil. J Crustacean Biol 2000; 20(3): 460-467.

[8] Mantelatto FL, Dominciano LCC. Pattern of shell utilization by the hermit crab Paguristes tortugae (Diogenidae) from Anchieta Island, southern Brazil. Sci Mar 2002; 66(3): 265-272.

[9] Mantelatto FL, Meireles AL. The importance of shell occupation and shell availability in the hermit crab Pagurus brevidactylus (Stimpson, 1859) (Paguridae) population from the southern Atlantic. Bull Mar Sci 2004; 75(1): 27-35.

[10] Meireles AL, Mantelatto FL. Shell use by the Pagurus brevidactylus (Anomura, Paguridae): a comparison between laboratory and field conditions. Acta Zool Sin 2005; 51(5): 813-820.

[11] Terossi M, Espósito DLA, Meireles AL, Biagi R, Mantelatto FL. Pattern of shell occupation by the hermit crab Pagurus exilis (Anomura, Paguridae) on the northern coast of São Paulo State, Brazil. J Nat Hist 2006; 40(1-2): 77-87.

[12] Scully EP. The effects of gastropod shell availability and habitat characteristics on shell utilization by the intertidal hermit crab Pagurus longicarpus Say. J Exp Mar Biol Ecol 1979; 37(2): 139152.

[13] Leite FPP, Turra A, Gandolfi SM. Hermit crabs (Crustacea: Decapoda: Anomura), gastropod shells and environmental structure: their relationship in southeastern Brazil. J Nat Hist 1998; 632: 1599-1608.

[14] Markham JC. Notes on growth-patterns and shell-utilization of the hermit crab Pagurus bernhardus (L.). Ophelia 1968; 5: 189-205.

[15] Fotheringham N. Effects of shell stress on the growth of hermit crabs. J Exp Mar Biol Ecol 1976; 23(3): 299-305.

[16] Angel JE. Effects of shell fit on the biology of the hermit crab Pagurus longicarpus (Say). J Exp Mar Biol Ecol 2000; 243: 169184.

[17] Melo, GAS. Manual e identificação dos Crustacea Decapoda do litoral brasileiro. São Paulo: FAPESP, Plêiade; 1999.

[18] Hebling NJ, Wernick AM. Notas sobre Isocheles sawayai (Forest, 1967) (Decapoda, Paguridea). Cienc Cult 1974; 26(7) (Suppl): 355.

[19] Sampaio CMS, Fausto-Filho J. Considerações sobre a bioecologia dos crustáceos decápodos da Enseada do Mucuripe (Fortaleza, Ceará, Brasil). Arq Cienc Mar 1984; 23: 11-24.

[20] Hebling NJ, Mantelatto FL, Negreiros-Fransozo ML, Fransozo A. Levantamento e distribuição de braquiúros e anomuros (Crustacea, Decapoda) dos sedimentos sublitorais da região da Ilha da Anchieta, Ubatuba (SP). Bol Inst Pesca 1994; 21 (único): 1-9.

[21] Coelho PA, Ramos-Porto M. Distribuição ecológica dos crustáceos decápodos marinhos do Nordeste do Brasil. Trabs Oceanog Univ Fed Pernambuco 1994/95; 23: 113-127.

[22] Negreiros-Fransozo ML, Fransozo A, Mantelatto FL, Pinheiro MAA, Santos S. Anomuran species (Crustacea, Decapoda) and their ecological distribution at Fortaleza Bay sublittoral, Ubatuba, São Paulo, Brazil. Iheringia, ser Zool 1997;(83): 187-194.

[23] Fransozo A, Mantelatto FL, Bertini G, Fernandez-Góes LC, Martinelli JM. Distribution and assemblages of anomuran crustaceans in Ubatuba Bay, north coast of São Paulo State, Brazil. Acta Biol Venez 1998; 18(4):17-25.

[24] Pinheiro MAA, Fransozo A, Negreiros-Fransozo ML. Seleção e relação com a concha em Isocheles sawayai Forest \& Saint Laurent, 1967 (Crustacea, Anomura, Diogenidae). Arq Biol Tecnol 1993; 36(4): 745-752.

[25] Fantucci MZ, Biagi R, Mantelatto FL. Record of intersexuality in the western Atlantic hermit Isocheles sawayai (Anomura, Diogenidae). J Mar Biolog Ass UK, Biol Rec 2007; 1: 1-3. (http://www.mba.ac.uk/jmba/pdf/5735.pdf).

[26] Campbell RC. Statistics for biologists. London: Cambridge; 1975

[27] Sant'Anna BS, Zangrande CM, Reigada ALD, Pinheiro MAA. Shell utilization pattern of the hermit crab Clibanarius vittatus (Crustacea, Anomura) in an estuary at São Vicente, State of São Paulo, Brazil. Iheringia, ser Zool 2006; 96(2): 261-266. 
[28] Hebling NJ. Aspectos biológicos de alguns crustáceos Paguridea do litoral do Estado de São Paulo. An Acad Bras Cienc 1978; 50(3): 424-425.

[29] Wernick AM. A influência da concha na taxa metabólica dos ermitões, Isocheles sawayai, Pagurus criniticornis e Clibanarius vittatus do litoral do Estado de São Paulo. Naturalia 1985; 10: 107-112.
[30] Benvenuto C, Gherardi F. Population structure and shell use in the hermit crab, Clabanarius erythropus: a comparison between Mediterranean and Atlantic shores. J Mar Biolog Assoc UK 2001; 81(1): 77-84.

[31] Rios, EC. Brazilian marine mollusks iconography. Rio Grande: Fundação Universidade do Rio Grande; 1975.

(C) Masunari et al.; Licensee Bentham Open.

This is an open access article distributed under the terms of the Creative Commons Attribution License (http://creativecommons.org/licenses/by/2.5/), which permits unrestrictive use, distribution, and reproduction in any medium, provided the original work is properly cited. 